\title{
The Influence of Social, Economic, and Environmental Factors on Health Quality in ASEAN
}

\author{
Muryani \& Fairidita Annisa Indra \\ Universitas Airlangga
}

\begin{abstract}
There is a serious problem in term of health over the past 70 years in developing countries, one of them is the quality of life expectancy. Even it has continued to increase but still there is a gap between developed and developing countries. The gap in life expectancy is assumed to be rooted in the differences in socio-economic conditions of different social groups. Health matter, especially in the ASEAN region, is an important issue that must be addressed. Therefore, this research has an objective to explore the influence of social, economic and environmental factors on health quality in ASEAN. The variables in this research are the impacts of population, urbanization, food production, GDP, health spending, and $\mathrm{CO} 2$ emissions on health in 9 ASEAN countries in the period from 2001-2015. The analysis method is a panel of regression data. The findings of the research are that all the independent variables have a significant effect on Health quality in ASEAN.
\end{abstract}

Keywords: health degree, urbanization, GDP, CO2, food production.

Terdapat masalah serius dalam hal kesehatan selama lebih dari 70 tahun terakhir di negara-negara berkembang, salah satunya adalah kualitas harapan hidup. Meskipun terus meningkat tetapi masih ada kesenjangan antara negara maju dan negara berkembang. Kesenjangan dalam harapan hidup diasumsikan berakar pada perbedaan dalam kondisi sosial-ekonomi kelompok sosial yang berbeda. Masalah kesehatan khususnya di kawasan ASEAN merupakan masalah penting yang harus dibenahi. Oleh karena itu, penelitian ini memiliki tujuan untuk mengeksplorasi pengaruh faktor sosial, ekonomi dan lingkungan terhadap kualitas kesehatan di ASEAN. Variabel dalam penelitian ini adalah dampak populasi, urbanisasi, produksi pangan, PDB, pengeluaran kesehatan, dan emisi CO2 terhadap kesehatan di 9 negara ASEAN pada periode 2001-2015. Metode analisis adalah panel data regresi. Temuan dari penelitian ini adalah bahwa semua variabel independen memiliki pengaruh yang signifikan terhadap kualitas kesehatan di ASEAN.

Kata-kata kunci: tingkat kesehatan, urbanisasi, GDP, CO2, produksi pangan. 
People always try to improve their social and economic status and achieve a better life. As a result, health improvement has become one of the most important for social goals (Colantonio et al. 2010). Health is one of the most important assets people possess. If people are careless about their health, it can cause physical and emotional impairment and also obstruct their lives. The life cycle model has explained how a person's health status can determine future income, wealth and consumption, it is very important to identify factors that contribute to the health of the population (Lilliard and Weiss 1997). Information about population health status helps the policy makers and practitioners in finding effective cost mechanisms, providing health services, and reallocating health resources to optimize spending on the benefits of health. Health in this study uses Life Expectancy indicators. Life expectancy is the average number of years a person will live after birth (Bilas et al. 2014). Life Expectancy is also one of the indicators used to assess the health status of the population, if life expectancy increases, the health status of the population also increases and extends life expectancy. A high degree of public health can be used as an indicator of the success of the health and socio-economic development programs within a particular population. The fundamental problem is that over the past 70 years, life expectancy has continued to increase, but a big gap still exists between developed and developing countries (Bilas et al. 2014). This gap in life expectancy is believed to be rooted in the differences in socio-economic backgrounds of different social groups. Life expectancy in developed countries is 75 years, higher than the average life expectancy in the world which range at 72. Life expectancy in developed countries is higher than developing countries because it has a strong economy and good health infrastructure and a high quality of life for its population. The opposite condition for developing countries which have lower life expectancy than developed countries but still higher than underdeveloped countries.

\section{Concept of Health Economy}

Health economy is the study of supply and demand as well as the impact of health service resources on the population (Meisa 2012). Health economics needs to be studied, because there is a relationship between health and economics. Health affects economic conditions, and similarly economics affects health standards. In rational thinking, everyone wants to be healthy. Health is the capital to work and live to develop offspring. Demand to be healthy is not the same between for all people. A person whose life needs are very dependent on his health will certainly have a higher demand for a good quality of health. For example, a professional athlete will pay more attention to his health than someone who is unemployed (Meisa 2012).

According to Murti (2013) there are many definitions of health economics. One of them defines health economics as the study of supply and demand for health service resources and the impact of health care resources on health care users. Obviously, the definition only represents a small percentage of topics studied in health economics. The health economy needs to be studied, because there is a relationship between health and economy. Because health affects economic conditions, and conversely economic conditions affect a person's health condition.

\section{Health Status}

The definition of health by the Ottawa Charter (1986) is a resource for everyday life, 
not just for healthy living (a positive plan prioritizes social and personal resources and physical strength). Ottawa classifies that health in individuals can be influenced by nine factors. These factors are peace or security, shelter, education, food, income, balanced ecosystems, sustainable resources, social justice, and equality. Understanding health according to the World Health Organization is a physical, mental and social welfare condition and not only the absence of disease or weakness. Individual health can reflect the condition of an individual's social status. Individual health also reflects social welfare, and therefore individual health can reflect the condition of an individual's social status.

Health is part of people's welfare. Health is also one of the goals of a country's development to improve socio-economic conditions. Health is more fundamental to forming physically stronger communities than the development goals because health is a prerequisite for increasing productivity. Productivity is one of the production inputs which will produce goods and services for unlimited community needs (Todaro and Smith 2006). Furthermore, Sarvalingam and Sivakumar (2009) argue that Todaro considers health as one of the resources needed for human welfare. There are so many concepts of health, one of which is nutritional status, morbidity and mortality rates, especially for women and children. Health is considered important because it plays a role in poverty alleviation and economic development. Increased health will increase people's productivity and skills and reduce absences at work. The direct impact on improving health is on improving the social and economic conditions of the community.

\section{Concept of Life Expectancy}

Quality of life owned by a country or region, describes the welfare of the people and the success of programs made by the government to improve the degree of human life. Related to quality of life there is an element of life expectancy in it (Ardianti et al. 2015). Life Expectancy is one indicator used to assess the health status of the population, meaning that if life expectancy increases, the health status of the population also increases and extends the life expectancy. The phenomenon of increasing life expectancy shows that the level of community welfare is increasing. Life Expectancy is defined as the age that a person born in a given year might achieve. Life expectancy is calculated using an indirect approach (Ardianti et al. 2015). There are two types of data used in calculating Life Expectancy, namely Children Born Alive and Children Still Alive. Meanwhile, to calculate the life expectancy index, the maximum value of life expectancy is used according to UNDP standards, where the highest number as the upper limit for calculating the index is used 85 years and the lowest is 25 years (UNDP standard).

Life expectancy is calculated based on the Death Rate according to age or Age Specific Death Rate, which data is obtained from death registration records for years so it is possible to make a death table. But because the population registration system in Indonesia has not run well, the indirect method is used to calculate Life Expectancy with the Mortpak program. The higher the Life Expectancy in an area, the more socio-economic development in the region is identified (BPS 2012). Some economists assume that health is an economic phenomenon, whether it is judged from stock or as an investment. So that health phenomena become a variable which can later be considered as a production factor to increase the value added of goods and services, or as a target of the goals to be achieved by both individuals, households and society, 
known as welfare goals (Ardianti et al. 2015). Therefore, health is considered as capital and has a positive rate of return both for individuals and for the community, so that in human development, the quality of human resources must have a high level of health in supporting high levels of productivity. Many things are behind the life expectancy in an area high or low. The success of health programs and socio-economic development in general can be seen in the increase health services, clean and healthy living behavior, education, and income that are described in gross regional domestic income (Ardianti et al. 2015). Therefore, health is considered as capital and has a positive rate of return both for individuals and for the community, so that in human development, the quality of human resources must have a high level of health in supporting high levels of productivity.

\section{Relationship between Population Growth and Life Expectancy}

Population growth is actually a dynamic balance between two forces that increase or reduce the population. Population development will be influenced by the number of babies born but simultaneously will also be reduced by the number of deaths that can occur in all age groups Population growth in a region is a development capital, because there is a workforce according to the development of the population, while on the other hand it will be a burden on the government because every soul will need life necessities, such as clothing, food, facilities and infrastructure. High population growth causes a population explosion; this greatly affects the quality of life. The quantity or population can be a potential or a burden for a country, it will become a potential if the population is balanced with other resources and has a good quality of life. High population growth will cause many problems related to population problems such as poverty, housing, employment and others. Increasing the number of people without an increase in employment will cause an increase in the number of unemployed people. In addition, natural resources that are relatively limited and tend to be able to remain inadequate to meet the needs of the population if the population continues to increase. The existence of problems that arise will have an impact on decreasing the quality of life of the community, so that life expectancy will decline as well (Christiani et al. 2012).

\section{Relationship between Urbanization and Life Expectancy}

Urbanization is one part of the process of population mobility that is interesting to discuss. The increasing flow of urbanization seems to be accompanied by the many economic centers built in urban areas, especially in the field of industrialization. Urbanization is the starting point of change or development of a city which is marked by the rate of growth of urban areas. Abbas (2002) provides an understanding of urbanization as a real movement and concentration of population which has an impact on its relationship with the new society which is motivated by social, economic, political and cultural factors. Urbanization should not only be in the context of demography because urbanization contains a multidimensional understanding. The urbanization of the demographic approach means as a process of increasing the concentration of the population in the city so that the proportion of the population living increases which is usually simply measured by the proportion of the population living in urban areas, the speed of change in the proportion, and changes in the number of urban centers. Villagers who move to the city will bring many benefits if they have the skills. However, if they do not have certain skills, they will find it difficult to get a job and even more marginalized. Problems that arise can be directly felt or indirect and longterm. The movement of people from one place affected by an outbreak to another will spread germs to residents in the new place. Long-term effects that arise include waste problems that can cause flooding, various infectious diseases such as diarrhea and typhus due to poor sanitation, malnutrition for mothers and children due to the 
inability to access nutritious food to poor social services. Based on the problems arising from urbanization, it will cause a decrease in quality of life, so that life expectancy decreases (Ningsih et al. 2013).

\section{Relationship between Food and Life Expectancy}

Food is a basic need for humans to be able to maintain life and food sufficiency for every person at all times which is a human right that deserves to be fulfilled. Food is a basic need for human beings and its fulfillment is the basic right of every citizen, so that food must be available in sufficient, safe, quality, nutritious quantities, varying in price affordable to people's purchasing power (Wirakartakusumah 2001). In accordance with Law No. 18 In 2012, food in the broad sense of everything derived from biological sources of agricultural, plantation, forestry, fisheries, livestock, waters and water products, both processed and unprocessed, which are intended as food or drinks for human consumption, including food additives, Food raw materials, and other materials used in the process of preparing, processing and/or making food or drinks. Food has a broad understanding, starting from essential food for healthy and productive human life including balance of calories, carbohydrates, proteins, fats, vitamins, fiber, and other essential substances and food consumed on social and cultural interests such as pleasure, fitness, beauty and so on. Therefore, food does not only mean staple food and clearly does not only mean rice, but food which is related to various other things (Krisnamurti 2003).

\section{Relationship between GDP Per Capita and Life Expectancy}

Healthy living is an objective life necessity so that each individual can improve his health status. On the other hand, the health of each individual is a subjective demand (health demand), where the demands of a healthy life, are not absolutely sought by themselves to improve health degrees that are facultative. Increased income per capita community, can indirectly indicate an increase in purchasing power which means there is an increase in living standards of the community so that the degree of public health has increased. Various types of assets at the household level will also affect the level of health. The following are some of the main things that indicate that per capita income can affect health: (1) an increase in per capita income for the availability of staple food in adequate quantities and nutrition is very important in survival, besides the quality of food hygiene is also very important in prevent disease transmission; (2) increasing income per capita can provide sufficient quantities of water and have adequate quality for bathing, washing and cleaning are variables that can affect health; (3) Poor ventilation and dense bedroom conditions in inhabited homes can affect the emergence of skin and respiratory infections in household members, therefore the availability of plumbing and maintenance of sewage pipes is very easy to maintain health; (4) Increasing income per capita can finance the treatment of diseases; (5) Increased income can provide adequate and adequate clothing to protect themselves from local climate conditions and reduce the incidence of skin infections and parasitic disorders. Therefore, increasing income per capita can make health status better.

\section{Relationship between CO2 Emissions and Life Expectancy}

Carbon dioxide (CO2) is one of the emissions produced by organic energy sources such as coal and petroleum. Carbon dioxide comes from burning fossil fuels in the energy, industrial and transportation sectors, forest fires and agriculture. Carbon dioxide is also produced by all living things in the process of respiration and is used by plants in the process of photosynthesis. Carbon dioxide has the ability to hold infrared in sunlight. Inflammation held by carbon dioxide carries heat radiation that cannot be reflected back by the Earth's atmosphere. This restrained heat then raises 
the earth's temperature higher than it should so that it triggers global warming and climate change. The phenomenon of increasing the volume of $\mathrm{CO}_{2}$ carbon dioxide emissions from time to time both at global, regional, and national levels in a country is a concern of both developed and developing countries. The increase in the volume of $\mathrm{CO} 2$ emissions occurs because of the increasing use of energy from organic materials (fossils), land use change activities and forest fires, and increased anthropogenic activities. In addition, the increase in the volume of $\mathrm{CO}_{2}$ emissions that has been considered has also resulted from the inefficiency of the combustion process produced from vehicle engines This happens together the increase in the number of motorized vehicles resulting in air pollution is also increasing. The negative impact that arises from the increasing number of excessive $\mathrm{CO} 2$ emissions, namely the greenhouse effect, where $\mathrm{CO} 2$ at the atmosphere can absorb heat energy and block the heat energy nets from the atmosphere to a higher surface. According to the WHO, the health effects of exposure to $\mathrm{CO} 2$ emissions in a short time can affect the reaction of pneumonia, ARI (upper respiratory infection) and others, while the long-term effects of $\mathrm{CO}_{2}$ emissions can improve symptoms of lower respiratory tract, exacerbations of asthma, decreased function pulmonary disease in children, increased chronic lung obstructive, decreased lung function in adults, decreased average life expectancy, and infant mortality Therefore, the level of health has declined along with the increase in $\mathrm{CO} 2$ emissions.

\section{Research Method}

This research employs a quantitative approach. According to Donmoyerin Given (2008), a quantitative approach is an approach to empirical studies to collect, analyze, and display data in numerical form rather than narrative. The sampling technique in the quantitative approach is done randomly. Data collection using research instruments and data analysis is quantitative and statistical with the aim of testing the hypotheses that have been established (Sugiono 2009). Meanwhile, the study uses statistic panel data regression method.

This study tries to explore the relationship between factors. The analytical model is useful in explaining the relationship between variables and the model has been developed based on previous studies. This study utilizes panel data regression model. The analysis model is written as follows:

LnDKit $=\alpha+\beta 1$ LnPOPit $+\beta 2$ LnURBNit $+\beta 3$ LnFoodit $+\beta 4$ LnPDBKAPit $+\beta 5$ LnBKit $+\beta 6 \operatorname{LnCO} 2 i t+\varepsilon i^{1}$

\section{Results and Discussion}

The condition of the countries in Southeast Asia in recent years has seen many changes in the health sector, but these health problems have not stopped and even new problems have emerged for the world of health in Southeast Asian countries. Based on this, health in the ASEAN region is also an important issue that must be resolved by

1 DK: Health Degree; POP: Population; URBN: Urbanization; Food: Food Production; PDBKAP: GDP per capital; BK: Health Spending; CO2: Carbon Dioxide 
the countries in Southeast Asia. For this reason, countries that are members of ASEAN have begun to hold meetings to cooperate with each other in overcoming the obstacles to the high degree of health (UNDP, 2014).

Figure 1

Average Life Expectancy in ASEAN Countries

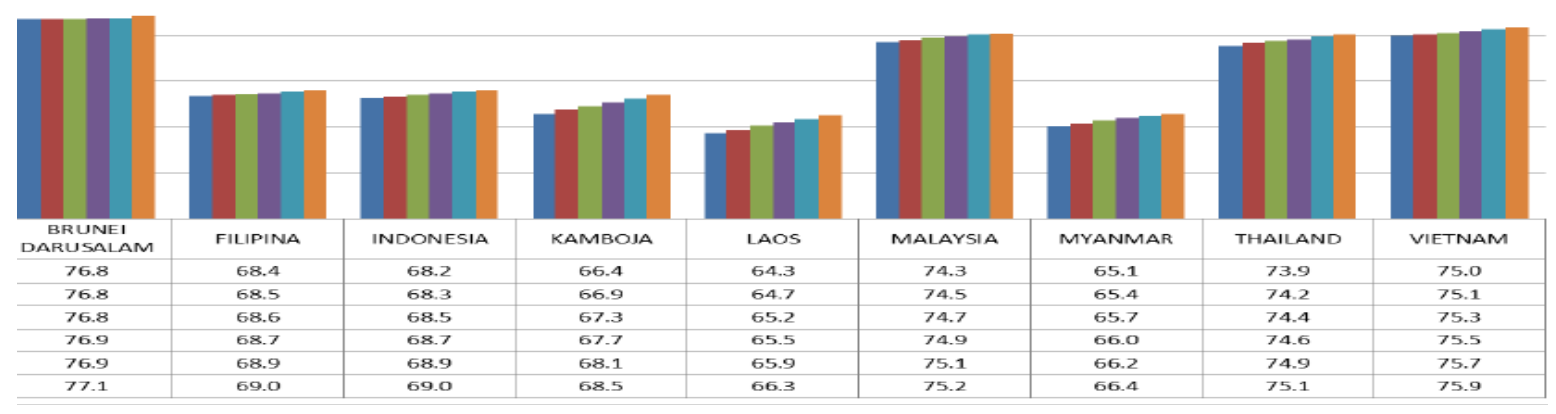

Source: World Bank

Countries that have low Life Expectations show that they have a lack of focus on health problems. Figure 1 shows the development of life expectancy in ASEAN countries. There are 9 countries that will be analyzed in this study. Singapore is already a developed country and thus is not included in the countries studied. In all the countries studied, life expectancy has been continuously increasing every year. Brunei Darussalam has a higher life expectancy compared to other countries, which is above 75 years, but the life expectancy in Brunei Darussalam has been relatively constant. Indonesia's life expectancy is relatively similar to the Philippines, but lags behind Malaysia and Thailand.

Other problems arise after analyzing Figure 1. There is an imbalance in health status in ASEAN member countries. An explanation is needed regarding the factors that influence health inequalities so they can design policies and programs to reduce these gaps. The World Health Organization (WHO) has organized a study involving many scientists, policy makers and former health officials from various countries around the world about the disparities in the health of these communities (Anggraini and Listyaningsih 2014).

\section{Population}

In particular, Indonesian States Law No.24 of 2013 article 1 point 9 states that population data is individual data or aggregate data that is structured as a result of population registration and civil registration activities. The population development causes the utilization of natural resources without consideration for sustainability. Population development causes increasing land requirements and the conversion of forests to other uses. Too much growth in population can lead to excessive use of resources.

Population plays an important role because it provides the labor needed to create economic activity. Population growth will affect the problem of the unemployment rate. A high population will also affect the size of the workforce. An increase in population 
will lead to an increase in the workforce. An increase in the workforce that is not followed by the availability of employment opportunities will lead to unemployment.

Table 1

\section{Average Population in ASEAN (in million people)}

\begin{tabular}{|c|c|}
\hline Countries & Average \\
\hline Brunei Darusalam & 24 \\
\hline Indonesia & 236 \\
\hline Cambodia & 14 \\
\hline Laos & 6 \\
\hline Myanmar & 50 \\
\hline Malaysia & 27 \\
\hline Filipina & 91 \\
\hline Thailand & 66 \\
\hline Vietnam & 85 \\
\hline
\end{tabular}

Source: World Bank

The diagram above shows the development of population growth in ASEAN countries. The largest population is in Indonesia. Indonesia's population is 236 million. The smallest population is in Laos. The population of Laos is only 6 million. Part of the reason for the small population is because the birth rate in Laos is still low compared to other countries.

\section{Urbanization}

The existence of excessive urbanization has caused various problems. Not only does it cause problems in the destination city, but it also creates problems in the abandoned villages. Problems that occur in the city include increasing poverty rates which results in the increase of slum settlements, urban crime and many other problems. In the villages there will also be problems including the reduction of human resources. Due to large portions of the inhabitants migrating to the city, the village does not experience any real development.

Table 2

Average Urbanization in ASEAN (in thousand people)

\begin{tabular}{|c|c|}
\hline Countries & Average \\
\hline Brunei & 283 \\
Darusalam & 115,000 \\
\hline Indonesia & 2,734 \\
\hline Kamboja & 1,881 \\
\hline Laos & 15,100 \\
\hline Myanmar & 18,800 \\
\hline Malaysia & 41,600 \\
\hline Filipina & 27,600 \\
\hline Thailand & 24,900 \\
\hline Vietnam & \\
\hline
\end{tabular}

Source: World Bank

The table shows that the development of urbanization in 9 ASEAN countries during 
2001-2015. The country that has the highest level of urbanization is Indonesia. From 2001-2015, the average level of urbanization in Indonesia was more than 100 million. Indonesia's urbanization is high due to narrow employment.

\section{Food Production}

At present there are global concerns about the sustainability of food production in line with the increasingly shifting agricultural land for housing, banking, industrial location due to an increase in population and industrial growth. In order to anticipate the future food demand in the ASEAN countries, the following is presented regarding the development of food production. In the future this increase in food productivity will be key to increasing food production. Therefore, efforts to produce innovations to increase productivity should be carried developed. In addition, counseling to accelerate the adoption of innovative technologies by farmers needs to be prioritized.

\section{Table 3}

\section{Presentation of Average Food Production Index in 9 ASEAN Countries}

\begin{tabular}{|c|c|}
\hline Countries & Average \\
\hline Brunei Darusalam & 283 \\
\hline Indonesia & 115000 \\
\hline Cambodia & 2734 \\
\hline Laos & 1881 \\
\hline Myanmar & 15100 \\
\hline Malaysia & 18800 \\
\hline Filipina & 41600 \\
\hline Thailand & 27600 \\
\hline Vietnam & 24900 \\
\hline
\end{tabular}

Source: World Bank

The table above shows the development of the average food production of ASEAN member countries during the period 2001-2015. The highest average food production is Brunei Darussalam with an average of index about 283. This shows that food production in Brunei Darussalam increased by 24 percent over the period of study compared to the previous years. This condition shows that Brunei Darussalam has an average production of safe food. Food production in all ASEAN countries is relatively safe. This is because the value of the food production index is above 100 .

\section{GDP per capita}

The economy of a country has an indicator that is used to assess whether the economy is going well or not. The indicator in assessing the economy must be used to determine the total income earned by all people in the economy. The correct and appropriate indicator in making these measurements is GDP. However, there are several things that are not included in the calculation of GDP such as the value of all activities that occur outside the market, environmental quality and income distribution. GDP per capita is a better tool to illustrate the standard of living of citizens (Mankiw 2006).

Countries that have a high GDP per capita generally have a high standard of living. 
Income differences reflect differences in quality of life: rich countries (reflected by high per capita income) have a better quality of life (reflected by, among others, life expectancy, health level, and level of education) compared to poor countries. In addition, the increase in per capita income reflects the emergence of improvements in the economic welfare of a community or population (Purba 2011).

\section{Conclusion}

There are 9 countries in ASEAN area have been analyzed in this study. Because Singapore is developed country so it is not included in the study. The fact, life expectancy has been continuously increasing every year in ASEAN countries and Brunei Darussalam is the highest, which is above 75 years and has been relatively constant year by year. Indonesia's life expectancy is relatively similar to the Philippines, but lags behind Malaysia and Thailand. The research utilizes a panel of regression data and the findings of the research are that all the independent variables have a significant effect on Health quality in ASEAN area. The variables are the population, urbanization, food production, health expenditure, GDP, the $\mathrm{CO} 2$ emission have a partially significant effect on the health degree. Also, simultaneously all the variables have a significant effect on health quality.

Based on the conclusions, there are two suggestions provided by this study. First, the governments of each ASEAN country should improve the aspects of education in disadvantaged regions. In addition, expanding employment in the lagging regions. Second, the governments of each ASEAN country should import if food shortages. The government can increase GDP per capita by increasing domestic output and also suppresses $\mathrm{CO}_{2}$ by planting trees in all regions of the country, and begins an effort towards reforestation. For further research, this topic can be developed by expanding the area of the State to be studied.

\section{References}

\section{Books}

Given, Robert,. 2008. Introduction to Quantitative Research Methodology: A Training Manual. New York: Free Press.

Mankiw, Gregory, 2006. Pengantar Ekonomi Makro (Edisi Ketiga). Jakarta: Salemba Empat

Sarvalingam, A.\&Sivakumar, M., 2009. Human Deprivation Index: A Measure of Multidimensional Poverty. Munich, Germany: Munich Personal RePEc Archive

Sugiyono, 2009. Metode Penelitian Kuantitatif, Kualitatif dan R\&D. Bandung: Alfabeta.

Todaro, Michael P. dan Stephen C. Smith, 2006. Pembangunan Ekonomi (edisi kesembilan, jilid I). Jakarta: Erlangga

\section{Journal}


Anggraini, Rakhmawati dan Lisyaningsih,. 2014. "Analisis Faktor-Faktor yang Mempengaruhi Angka Harapan Hidup di Provinsi Jawa Barat”,. Jurnal Ekonomi Pembangunan Indonesia,. Vol. 3 (2): 23-31.

Balan, Feyza, 2016. "Environmental Quality and its Human Health Effects: A Causal Analysis for the EU-25”, International Journal of Applied Economics, 13 (1):57-71.

Bilas, V, Franc, S, Bosnjak, M, 2014. "Determinant Factors of Life Expectancy at Birth in the European Union Countries", Journal of Business \& Economic Statistics, 38(1):1-9.

Colantonio, Ronald, et al., 2010. "Analysis determinant of life expectancy in South Africa", Journal of economics and Business, 3(11): 187-198.

Christiani, Ayu et al., 2012. "Dampak Faktor Sosial Dan Lingkungan Terhadap Kesehatan Masyarakat Kabupaten Ponorogo", Jurnal Ekonomi dan Bisnis, 3(9):113 .

Krisnamurti, Muhammad, 2003. "Ketahanan Pangan dan Kesehatan Masyarakat di Kabupaten Jember”, Jurnal Ilmiah Universitas Jember, 7(9):111- 122.

Meisa, Rina, 2012. “Analisis Ekonomi Kesehatan di Provinsi Papua”, Jurnal Ekonomi dan Bisnis, 3(4):123-131.

Murti, Rima, 2013. “Analisis Pengaruh Pendapatan Per Kapita Terhadap Kesehatan Warga Jemursari”, Jurnal Kesehatan Masyarakat, 2(1): 1-12.

Ningsih, Amanda et al., 2013. "Hubungan Urbanisasi dan Lingkungan Masyarakat", Jurnal Ekonomi Pembangunan dan Perencanaan, 7(3):45-54.

Purba, Muhammad Asa'at, 2011. "Analisis Pengaruh Pendapatan Perkapita, Impor, Penanaman Modal Asing, Penanaman Modal Dalam Negeri Dan Jumlah Uang Beredar Terhadap Laju Inflasi di Indonesia Periode Tahun 1979-2009”, Jurnal Penelitian Inovasi, September 2012.

Rochaida, Eny, 2016. "Dampak Pertumbuhan Penduduk Terhadap Pertumbuhan Ekonomi Dan Keluarga Sejahtera Di Provinsi Kalimantan Timur", Forum Ekonomi, 18 (1).

\section{Other Sources}

Ardianti et al., 2015. Faktor- Faktor yang mempengaruhi angka harapan hidup di Kabupaten Jember, artikel ilmiah mahasiswa, Universitas Jember.

Liliard, Carlos, and Weiss, Robert.1997. Analysis of Life Expectancy in South Africa. IMF Working Paper No. 17719.

United National Development Program (UNDP). 2014. World Health Report.

Wirakartakusumah. 2001. Pelabelan Pangan. Dalam Hardiansyah, Atmojo SM, editor. Pengendalian Mutu dan Keamanan Pangan. Jakarta: 55 Perhimpunan Peminat Gizi dan Pangan (PERGIZI PANGAN) Indonesia, Perhimpunan Ahli Teknologi Pangan Indonesia (PATPI) danInstitut Pertanian Bogor, bekerjasama dengan Proyek $\mathrm{CHN}_{3}$, Direktorat Jenderal Pendidikan Tinggi 
The Influence of Social, Economic, and Environmental Factors on Health Quality in ASEAN 